\title{
MENGELOLA TAMAN BUDAYA DI LAPANGAN DEWATA DENGAN PROTOKOL KESEHATAN DI ERA NEW NORMAL
}

\author{
Tina Melinda ${ }^{1) *}$, David Sukardi Kodrat ${ }^{2)}$, dan Imelda Ritunga ${ }^{3)}$ \\ ${ }^{12}$ Magister Management Program, Universitas Ciputra \\ ${ }^{3}$ Fakultas Kedokteran, Universitas Ciputra \\ *email: tina.melinda@ciputra.ac.id
}

\begin{abstract}
Abstrak
Desa Wage kecamatan Taman kabupaten Sidoarjo adalah tempat strategis, karena dikelilingi oleh perusahaan besar. Perekonomian desa Wage mayoritas dari sektor perniagaan seperti menjual kuliner. Saat pandemic Covid-19 agar dapat tetap melakukan kegiatan perekonomian maka masyarakat harus betul-betul menjalankan Pola Hidup sehat. Untuk itu Universitas Ciputra bekerja sama dengan BUMDes Wage Bersinar melaksanakan kegiatan sebagai berikut: pertama menjadikan pengurus Bumdes sebagai role model menjalankan protokol Kesehatan dan menjadikan mayarakat desa Wage sadar akan pentingnya pola hidup sehat agar tetap dapat menjalankan perekonomian. Dalam mengelola taman budaya, maka harus menggunakan protokol Kesehatan, mengingat taman ini adalah multi fungsi selain sebagai sentra kuliner juga sebagai wadah kegiatan masyarakat seperti berolah raga dan pertemuan lain. Metode yang digunakan adalah (1) sosialisasi untuk memberikan pemahaman kepada masyarakat akan pentingnya $3 \mathrm{M}$ (2) pelatihan dan demonstrasi mengenai cara mencuci tangan yang benar (3) stimulan empowering dengan memberikan spanduk, poster, masker dan tangki tempat cuci tangan dan (4) asset based community development dengan memperkuat kapasitas masyarakat mengidentifikasi prioritas, peluang untuk mendorong dan mempertahankan perubahan lingkungan yang positif. Keberhasilan gerakan mengelola Taman Budaya Dewata dengan protokol Kesehatan dan aman digunakan untuk menunjang kegiatan desa dan menjalankan ekonomi setempat, serta dapat menjadi contoh bagi lokasi lain yang memiliki sarana yang sama
\end{abstract}

Kata kunci: taman budaya, new normal, protokol Kesehatan

\begin{abstract}
Wage Village, Taman sub-district, Sidoarjo regency is a strategic place, because it is surrounded by large companies. The majority of Wage's economy is from the commercial sector, such as selling culinary. During the Covid-19 pandemic in order to continue carrying out economic activities, people must really practice a healthy lifestyle. For this reason, Ciputra University collaborates with BUMDes Wage Bersinar to carry out the following activities: first to make Bumdes administrators a role model for implementing Health protocols and to make the Wage village community aware of the importance of a healthy lifestyle in order to continue to run the economy. In managing a cultural park, health protocols must be used, considering that this park is multi-functional apart from being a culinary center as well as a forum for community activities such as sports and other meetings. The methods used are (1) socialization to provide understanding to the community of the importance of $3 M$, (2) training and demonstrations on how to wash hands properly, (3) empowering stimulants by providing banners, posters, masks and hand washing tanks, and (4) asset based community development by strengthening the capacity of the community to identify priorities, opportunities to encourage and sustain positive environmental changes. The success of the movement to manage the Taman Budaya Dewata with Health protocols and safely used to support village activities and run the local economy, and can be an example for other locations that have the same facilities
\end{abstract}

Keywords: cultural park, new normal, health protocol

\section{PENDAHULUAN}

Desa Wage kecamatan Taman merupakan desa dengan penduduk terpadat di Kabupaten Sidoarjo dengan luas $207 \mathrm{Ha}(\mathrm{BPS}, 20017)$. Desa ini memiliki lebih dari 23.000 jiwa dengan potensi ekonomi yang baik. Hal ini disebabkan karena Desa Wage dikelilingi oleh lahan kering (BPS, 20017) dan beberapa komplek perumahan baru sehingga kebanyakan penduduknya memiliki mata pencarian 
dibidang perdagangan dengan produksi utama makanan-minuman, kerajinan, tas sopeso dan sabun.

Selain itu, Desa Wage mempunyai tiga modal utama untuk melangkah menjadi Desa Wisata Budaya. Ada campursari Arum Bawana, batik tulis dan makam mbah Ratu Ayu (Sidoarjokini, 2020).

Desa Wage merupakan bagian dari wilayah Kabupaten Sidoarjo. Kabupaten ini merupakan daerah di Jawa Timur yang memiliki tren pertumbuhan signifikan dari warganya yang terpapar Covid 19. Kecamatan Taman merupakan kecamatan yang warga terpapar Covid 19 nya tertinggi dibandingkan dengan kecamatan lain (Gambar 1). Dengan demikian, ketika diberlakukan Pembatasan Sosial Berskala Besar (PSBB) sebanyak 3 periode di wilayah Surabaya Raya, maka banyak warga yang penghasilannya berkurang atau bahkan tidak memiliki penghasilan lagi.

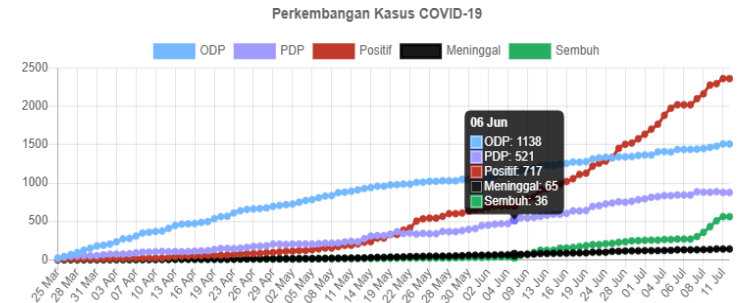

Gambar 1. Trend peningkatan kasus Covid 19 di Kabupaten Sidoarjo

Sumber: (Pusat Informasi Dan Komunikasi COVID-19 KABUPATEN SIDOARJO, 2020)

Berdasarkan dari data diatas, dapat dilihat bahwa per tanggal 6 juni 2020, jumlah $\mathrm{ODP}=1.138, \quad \mathrm{PDP}=521$, Positif 717, meninggal 65 dan sembuh 36 orang. Hal ini harus menjadi perhatian bersama karena tren dari kasus terinveksi covid ini masih terus meningkat dari hari ke hari.

Desa Wage akan mendapat pantauan khusus dan kemungkinan bisa diterapkan Pembatasan Sosial Berskala Lokal yang akan mempengaruhi perekonomian masyarakat, karena mayoritas penduduk adalah UMKM yang menjual makanan sebagai supplier dari dua perusahaan besar yaitu Maspion dan PT Ispatindo.

Menurut Becker (Marni \& Margiyati, 2013) perilaku sehat yaitu perilaku- perilaku yang terkait dengan kegiatan untuk mempertahankan serta meningkatkan kesehatan. Kebutuhan untuk mempertahankan maupun meningkatkan kesehatan tersebut dibutuhkan oleh setiap orang (Short \& Mollborn, 2015). Dengan demikian, diharapkan Desa Wage bisa menjadi percontohan dalam MENGELOLA TAMAN BUDAYA DI LAPANGAN DEWATA DENGAN PROTOKOL KESEHATAN DI ERA NEW NORMAL.

\section{METODE PELAKSANAAN}

Lokasi pelaksanaan Taman Budaya di Lapangan Dewata, Desa Wage, Kecamatan Taman. Program diawali dengan melakukan koordinasi antara Tim Universitas Ciputra, Tim BUMDes dan Tim Perangkat Desa Wage. Koordinasi pertama dilakukan dengan zoom pada tanggal 25 Agustus 2020. Setelah terjadi kesepakatan dalam koordinasi pertama dilanjutkan dengan Koordinasi Kedua pada tanggal 30 September 2020, untuk meninjau Taman Budaya di Lapangan Dewata, Desa Wage. Setelah disetujui lokasi untuk pemasangan spanduk dan poster kampanye 3M dan 3 WAJIB (3M: Memakai masker, Menjaga Jarak, Mencuci tangan pemasangan dan 3 WAJIB: Wajib meningkatkan imunitas, Wajib patuh pada protokol kesehatan dan Wajib menjalankan ibadah sesuai agama dan kepercayaan masing-masing).

Metode yang diterapkan dalam pemberdayaan masyarakat pada kegiatan pengabdian masyarakat ini adalah: (1) sosialisasi untuk memberikan pemahaman kepada masyarakat akan pentingnya $3 \mathrm{M}$ dan 3 WAJIB., (2) pelatihan dan demonstrasi mengenai bagaimana cara mencuci tangan yang benar menurut WHO, (3) stimulan empowering dengan memberikan spanduk, poster, masker dan 4 buah tangki dan tempat cuci tangan yang diletakan pada lokasi strategis pada Taman Budaya di Lapangan Dewata, Desa Wage, dan (4) asset based community development dengan memperkuat kapasitas masyarakat dengan mengidentifikasi prioritas dan peluang untuk mendorong dan mempertahankan perubahan lingkungan yang positif berdasarkan tiga komponen penting yaitu fokus berbasis tempat, membangun aset dan meningkatkan kualitas hidup (Chaskin et al., 2017; Craig, 2008; Moscardo, 2008; Squires, 2002; Theodori, 2005)(Chaskin et al., 2017; Craig, 2008; Theodori, 2005) (Craig, 2008; Theodori, 2005) 


\section{BAHAN DAN ALAT}

Bahan dan alat yang digunakan dalam rangka sosialisai pengelolaan taman budaya pada era new normal adalah spanduk, poster, masker dan tanki cuci dan tempat cuci tangan.

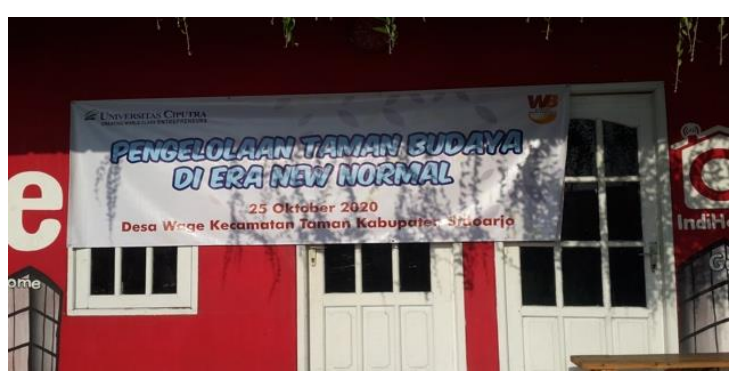

Gambar 2. Spanduk sosialisasi Pengelolaan Budaya di Era New Normal

Sumber: dokumentasi Pelaksana tim abdimas

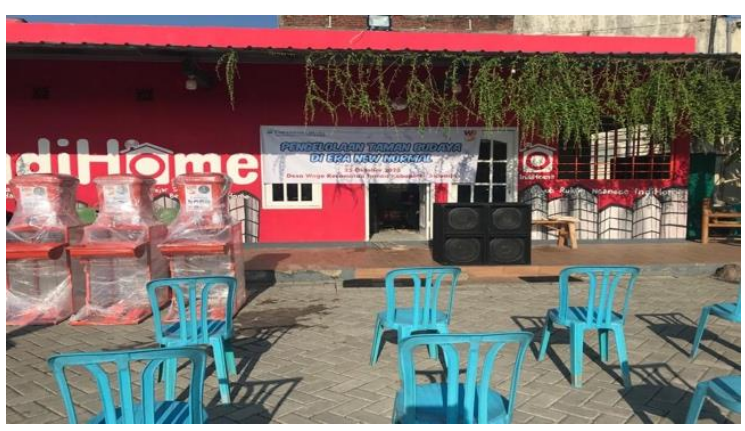

Gambar 3. Tangki air untuk cuci tangan

Sumber: dokumentasi Pelaksana tim abdimas

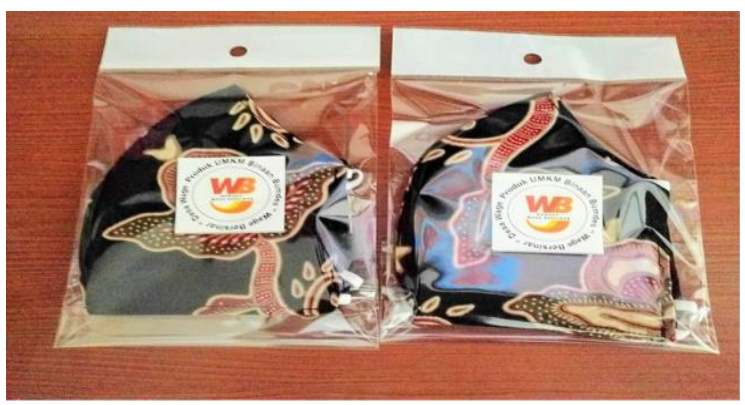

Gambar 4. Masker dari mitra (BUMDES Wage Bersinar)

Sumber: dokumentasi Pelaksana tim abdimas

\section{HASIL DAN PEMBAHASAN}

Ada tiga tahapan penting pelaksanaan Pengabdian Masyarakat ini yatu (1) Koordinasi pada tgl,25 Agustus 2020 dan 30 September 2020 (2) melakukan asset based community development dengan melihat kapasitas, prioritas dan peluang Desa Wage di tengah-tengah pandemik Covid 19, (3) sosialisasi untuk mengenalkan dan memperkual 3M dan 3 WAJIB, (4) pelatihan dan demonstrasi pelaksanaan $3 \mathrm{M}$, (5) serah terima spanduk, poster, master, tangki dan tempat cuci tangan, dan (6) evaluasi pelaksanaan pengabdian masyarakat.

\section{Tahap Koordinasi}

Koordinasi dilakukan pada tanggal 25 Agustus 2020 yang dihadiri oleh Pengurus BUMDES wage Bersinar, pengusaha UMKM dan Lurah Desa Wage Kecamatan Taman Kanuptaen Sidoarjo. Dengan menggunakan media online/ Zoom Materi yang dibicarakan pada tahap koordinasi ini adalah: pengelolaan taman budaya Dewata dengan mematuhi protocol Kesehatan sebagai tempat masyarakat desa wage untuk melakukan aktivitas sosialisasi dan juga wadah bagi para UMKM untuk memasarkan produknya. Hasil yang disepakati pada tahap koordinasi ini adalah: tim abdimas dari Universitas Ciputra akan membantu untuk pengadaan tangka tempat cuci tangan dan juga membantu sosialisasi pada masyarakt desa Wage untuk selalu ingat $3 \mathrm{M}$ (memakai masker, mencuci tangan dan menjaga jarak).

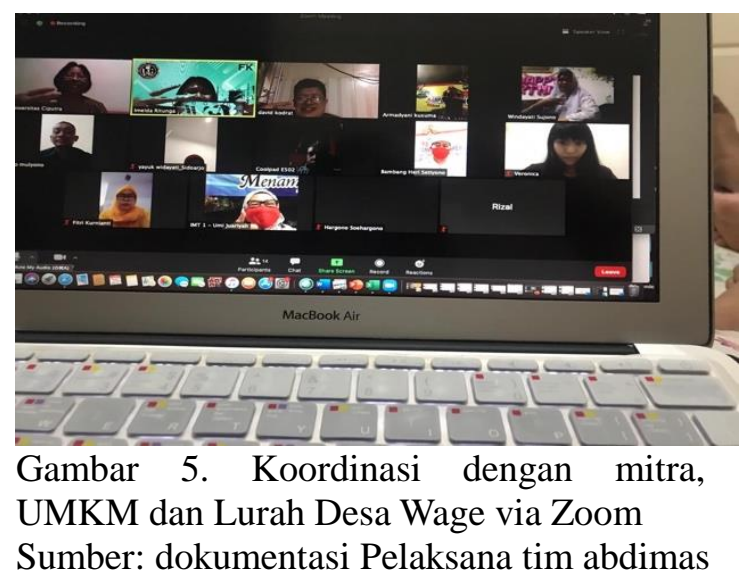

Koordinasi kedua dilaksanakan tgl 30 September 2020, dengan tim pelaskana abdimas Universitas Ciputra berkunjung ke Desa Wage, Kecamatan Taman Kabupaten Sidoarjo untuk melakukan peninjauan lapangan tempat akan dilaksanakan kegiatan sosialisasi. Pertemuan tersebut juga dihadiri oleh pengurus BUMDES Wage Bersinar, pengusaha UMKM dan Juga Lurah Desa Wage. Pada pertemuan ini dibahas adalah rencana untuk pelaksanaan sosialisasi dan juga hal-hal teknis terkait dengan kegiatan tersebut. Pada saat itu juga diserahkan secara simbolis tangka air untuk tempat cuci tangan dari tim pelaksana abdimas Universitas Ciputra kepada Bapak Lurah Desa Wage dengan disaksikan oleh pengurus Bumdes 
Wage Bersinar selaku mitra dari Universitas Ciputra.

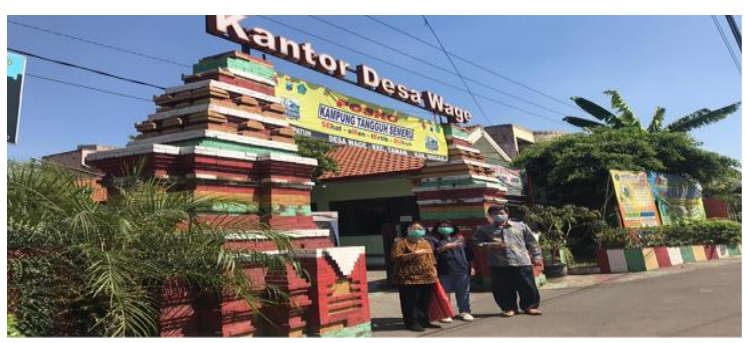

Gambar 6. Tim abdimas Universitas Ciputra berkunjung ke Kantor Desa Wage

Sumber: dokumentasi Pelaksana tim abdimas

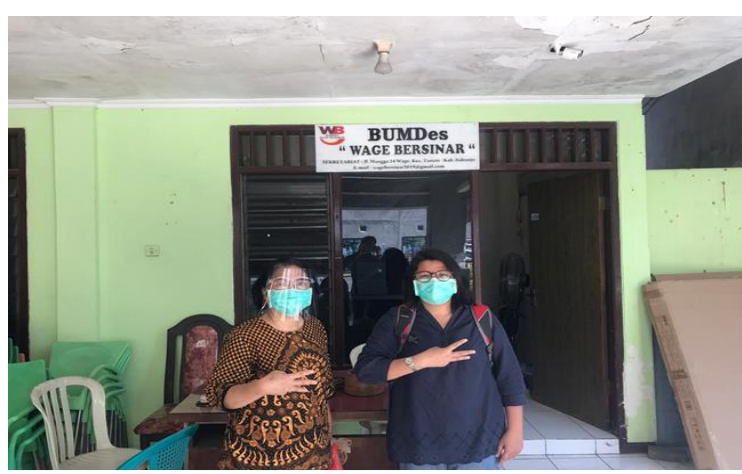

Gambar 7. Melakukan koordinasi dengan Mitra (BUMDES Wage Bersinar)

Sumber: dokumentasi Pelaksana tim abdimas

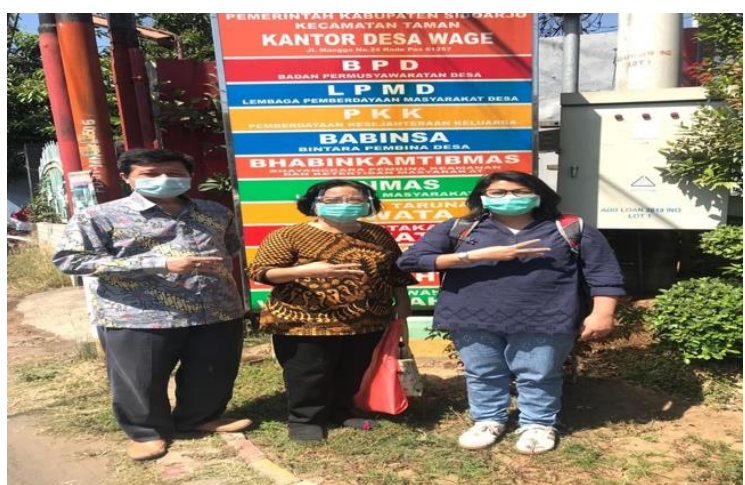

Gambar 8. Persiapan untuk meninjau lokasi taman budaya Dewata

Sumber: dokumentasi Pelaksana tim abdimas

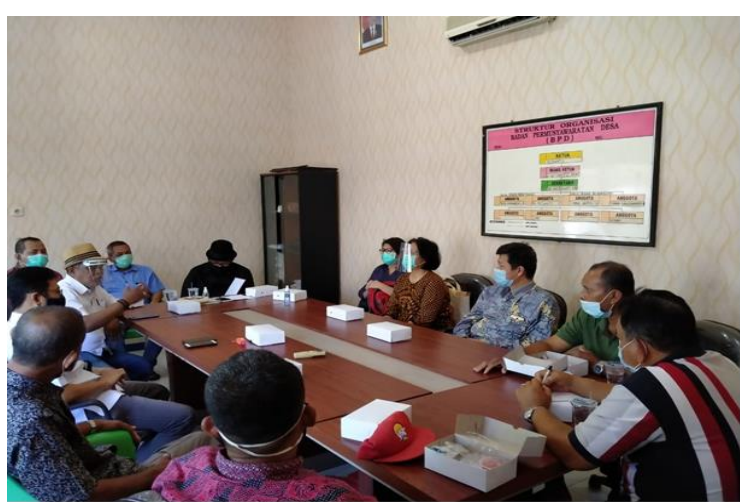

Gambar 9. Suasana koordinasi dengan mematuhi protokol Kesehatan
Sumber: dokumentasi Pelaksana tim abdimas

\section{Tahap Asset Based Community Development}

Langkah pertama dengan mengidentifikasikan aset yang ada di Desa Wage. Aset Desa dapat dikelompokkan menjadi tiga yaitu Modal Fisik, Modal Manusia dan Modal Sosial. Dari hasil observasi dan tanya-jawab dengan pengurus BUMDES dan Perangkat Desa Wage sebagai berikut.

Modal Fisik di Desa Wage adalah Makam Mbah Ratu Ayu, Pasar Desa Wage, Pusat Kuliner Desa Wage, Lapangan Dewata. Modal fisik ini sangat cocok untuk menjadikan Desa Wage sebagai Desa Wisata Budaya.

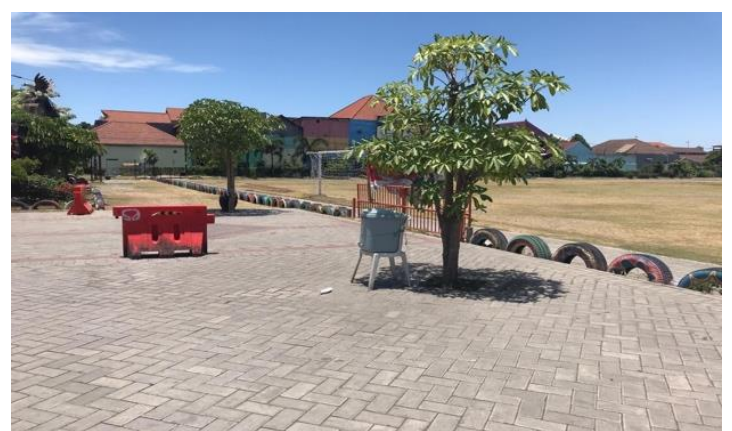

Gambar 10. Lapangan Dewata Desa Wage Kecamatan Taman, Kabupaten Sidoarjo Sumber: dokumentasi Pelaksana tim abdimas

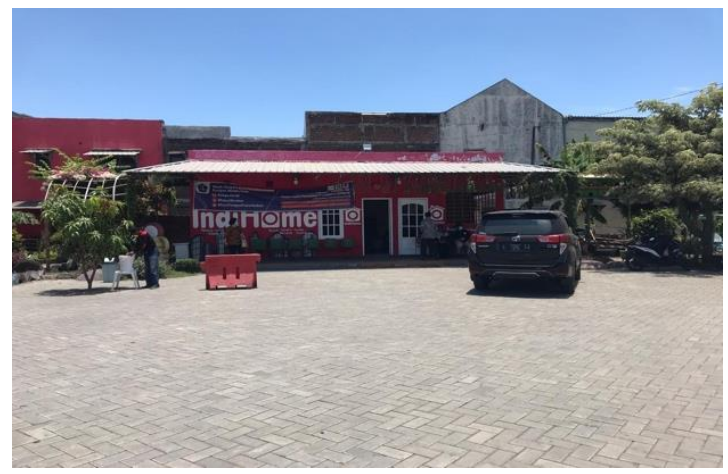

Gambar 11. Lokasi untuk mengadakan karawitan

Sumber: dokumentasi Pelaksana tim abdimas

Modal Manusia yang ada di Desa Wage berupa kemampuan atau keterampilan menggolah makanan dan minuman, keterampilan membuat handycraft, keterampilan membatik, keterampilan berkesenian campur sari, dan keterampilan berdagang. Modal manusia ini ini merupakan 
modal dasar entrepreneur.

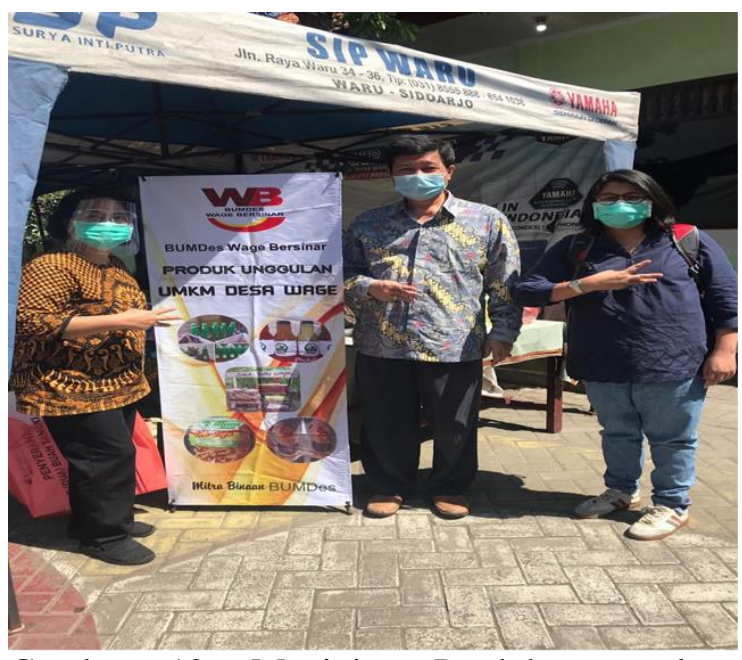

Gambar 12. Meninjau Produk unggulan UMKM desa Wage

Sumber: dokumentasi Pelaksana tim abdimas

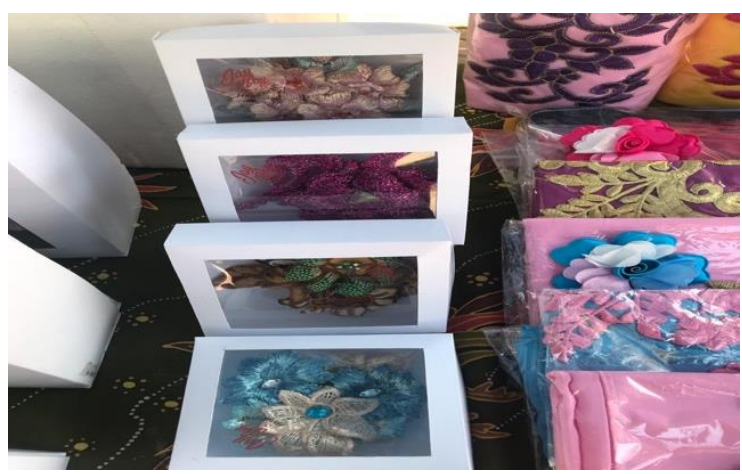

Gambar 13. Produk unggulan handicraft UMKM desa Wage

Sumber: dokumentasi Pelaksana tim abdimas

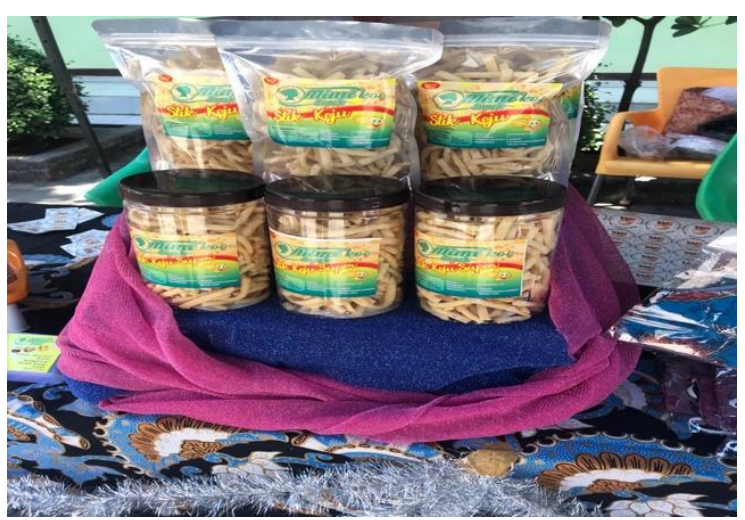

Gambar 14. Produk Snak UMKM desa Wage

Sumber: dokumentasi Pelaksana tim abdimas

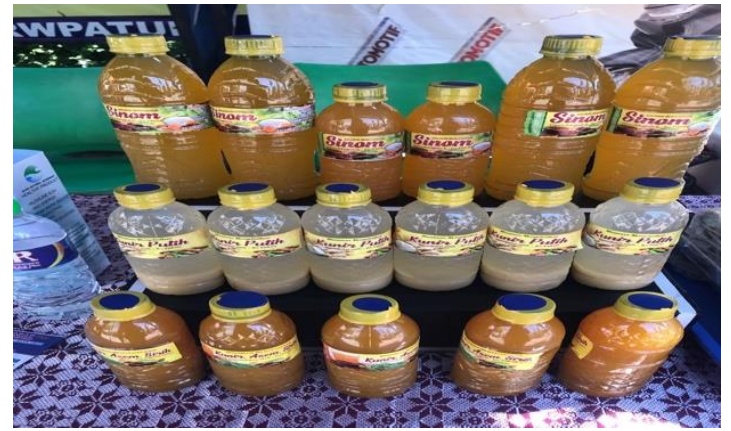

Gambar 15. Produk minuman UMKM Desa Wage

Sumber: dokumentasi Pelaksana tim abdimas

Pada umumnya, Modal Sosial di Desa Wage berhubungan dengan Ratu Ayu. Setiap masyarakat yang melaksanakan hajatan, harus sowan ke makam Mbah Ratu Ayu sebagai pedunden. Sarat tang tidak boleh ditinggalkan ayam ingkung yang mendampingi nasi tumpeng, lauk-pauk lain, jajan pasar, serta kembang setaman. Setiap tahun di Desa Wage diadakan bersih desa untuk menangkal segala mara bahaya dan sebagai rasa syukur karena Desa Wage telah memberi kenyamanan, aman dan tentram tidak ada kejadian yang tidak diinginkan.

\section{Langkah}

kedua

adalah PERENCANAAN. Perencanaan dilakukan dengan melibatkan berbagai stakeholder yaitu tim Universitas Ciputra, tim BUMDes Wage Bersinar, dan Tim Perangkat Desa Wage. Halhal yang direncanakan berupa:

\section{Tahap Sosialisasi}

Sosialisasi yang dilakukan dengan menjelaskan penilaian umum (pengetahan Covid 19, membuat virus tidak aktif, gejala Covid 19, penularan Covid 19, dan mencegah penularan Covid 19 dengan konsep 3M (Memakai masker, Mencuci tangan dan menjaga jarak) dan 3 WAJIB.

Tabel 1. Hasil pretes untuk mengetahui pemahaman pengurus BUMDes Wage bersinar tentang Corona Virus (Covid) 19 


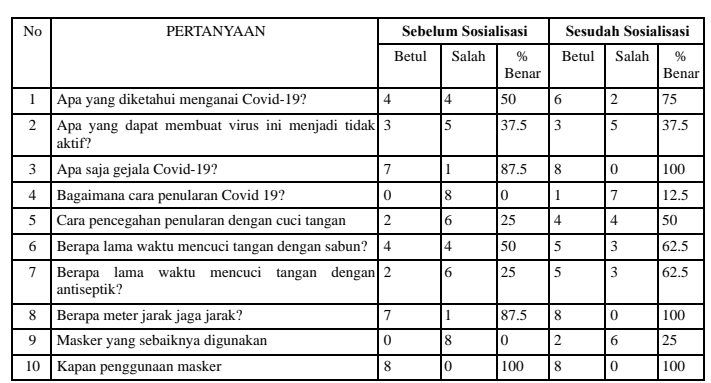

Sumber: data diolah

Hasil sosialisasi menunjukkan bahwa dari 10 pertanyaan yang dilakukan kepada 8 orang menunjukkan PERBEDAAN PENGETAHUAN, SKILL DAN PERILAKU sebelum sosialisasi dan setelah sosialisasi.

Pengetahuan peserta tentang Covid-19 setelah sosialisasi mengalami peningkatan dari $50 \%$ menjadi $75 \%$. Sayangnya, pengetahuan tentang Covid 19 yang dipahami ini HANYA YANG BERSIFAT PRAKTIS. Pengetahuan terkait dengan perkembangan virus dan cara penularan virus belum dipahami dengan baik. Hasil survei menunjukkan pengetahuan responden terkait dengan perkembangan virus tetap sama sebelum dan sesudah sosialisasi yaitu 37,5 persen. Pengetahuan responden terkait dengan cara penularan Covid, ada sedikit perubahan dari 0 persen menjadi 12,5 persen.

Terkait dengan skill dan perilaku responden sebelum dan sesudah SOSIALISASI MENGALAMI PERUBAHAN. Peningkatan keterampilan responden membaca gejala-gejala Covid menjadi $100 \%$ dan keterampilan untuk selalu menjaga jarak menjadi 100\%. Sedangkan keterampilan mencuci tangan hanya meningkat sedikit dari 50 persen menjadi 62,5 persen. Hal ini disebabkan karena responden merasa waktu yang dibutuhkan untuk mencuci tangan sesuai dengan standar WHO terlalu lama.

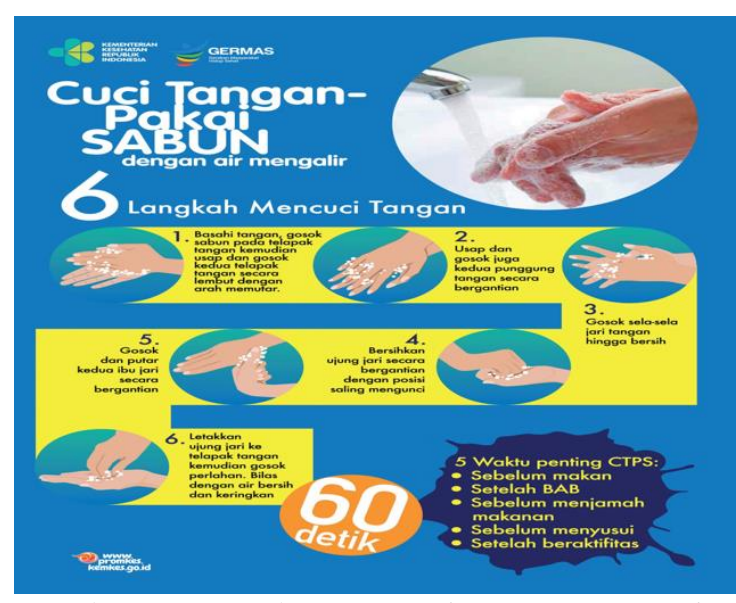

Gambar 16. Tahapan cuci tangan sesuai anjuran dari WHO (World Health Organization)

Sumber: (Kementrian-Kesehatan \& RepublikIndonesia, 2020)

Pada Gambar 16. dijelaskan proses cuci tangan yang benar harus mengikuti 6 tahapan seperti disarankan dari WHO (World Health Organization)

1. Basahi tangan, gosok sabun pada telapak tangan kemudian usap dan gosok kedua telapak tangan secara lembut dengan arah memutar

2. Usap dan gosok juga kedua punggun tangan secara bergantian

3. Gosok sela-sela tangan hingga bersih

4. Bersihkan ujung jari secara bergantian dengan posisi saling mengunci

5. Gosok dengan putar kedua ibu jari secara bergantian

6. Letakan ujung jari ketelapak tangan kemucian gosok perlahan. Bilas dengan air bersih dan keringkan.

Untuk itu peserta sosialisasi mulai dari anak-anak sampai orang dewasa diminta untuk melakukan roleplay cara mencuci tangan dengan mengikuti 6 langkah setelah diberi petunjuk oleh tim pelaksana abdimas.

Tahap Pelatihan dan Demonstrasi: 


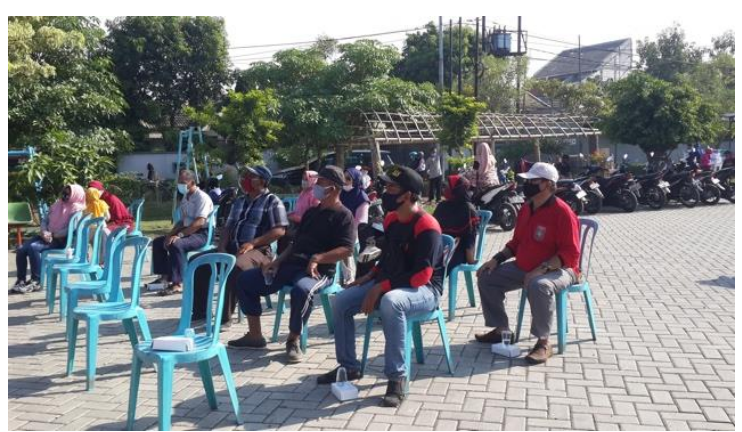

Gambar 17. Peserta Sosialisasi pengelolaan taman budaya dengan mematuhi protokol kesehatan

Sumber: dokumentasi Pelaksana tim abdimas

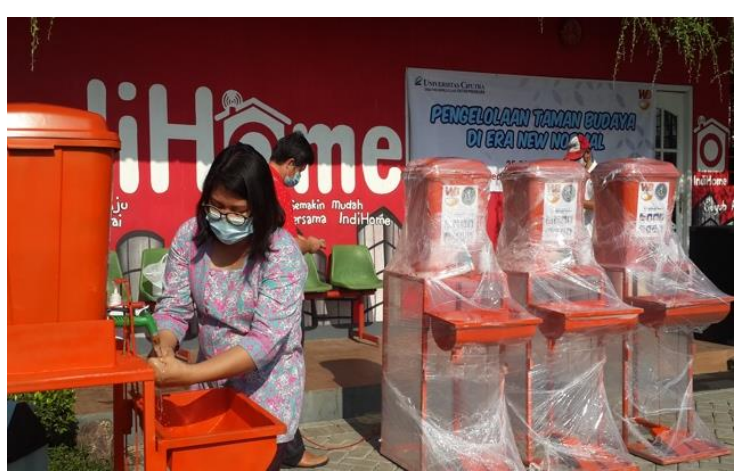

Gambar 18. Tim pelaksana abdimas memberi contoh mencuci tangan sesuai standar WHO

Sumber: dokumentasi Pelaksana tim abdimas

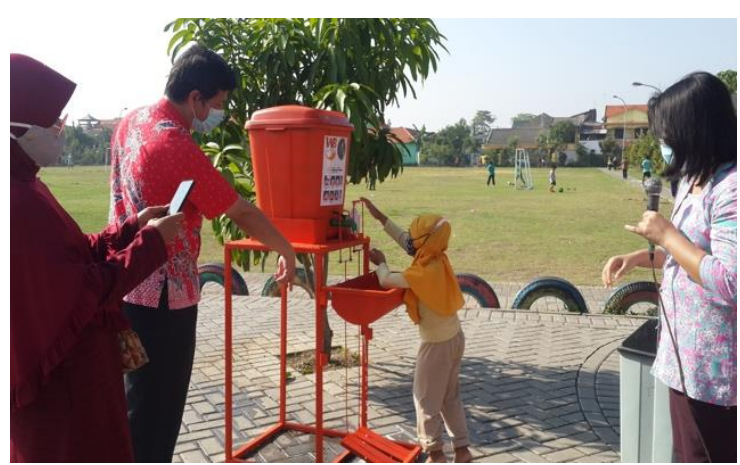

Gambar 19. Roleplay cuci tangan oleh seorang anak dengan dipandu oleh tim pelaksana abdimas

Sumber: dokumentasi Pelaksana tim abdimas

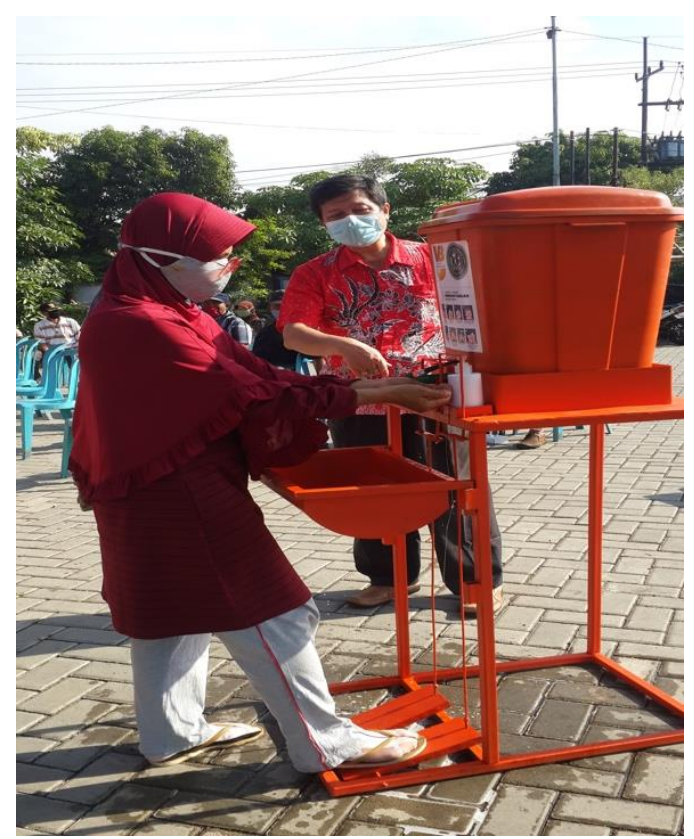

Gambar 20. Roleplay cuci tangan oleh seorang Ibu dengan dipandu oleh tim pelaksana abdimas

Sumber: dokumentasi Pelaksana tim abdimas

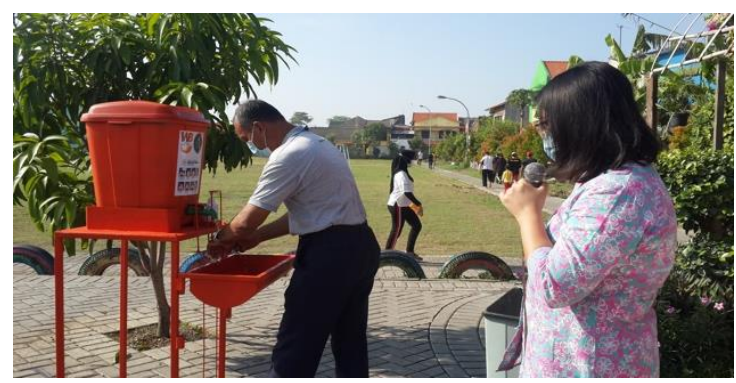

Gambar 21. Roleplay cuci tangan oleh seorang Bapak dengan dipandu oleh tim pelaksana abdimas

Sumber: dokumentasi Pelaksana tim abdimas

\section{Tahap Serah Terima}

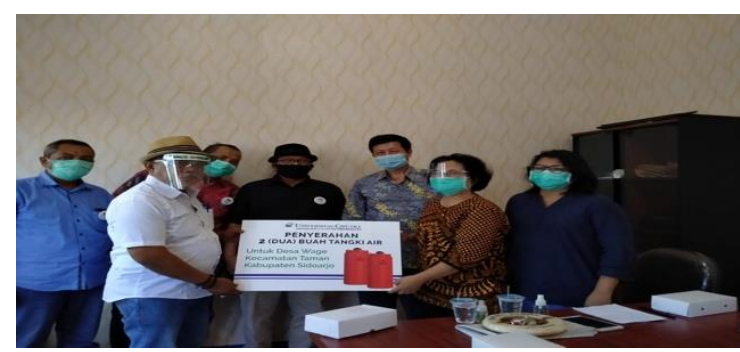

Gambar 22. Penyerahan tanki air tempat cuci tangan

\section{Tahap Evaluasi}

Evaluasi diberikan pada akhir acara pengabdian masyarakat dengan memberikan kuisioner yang bertanya tentang: (1) hal yang dirasakan paling MENARIK dan bermanfaat pada saat sosialisasi, pelatihan dan 
demonstrasi dan (2) hal yang dirasakan paling TIDAK MENARIK dan bermanfaat pada saat sosialisasi, pelatihan dan demonstrasi.

Tabel 2. Hal yang Paling Menarik Pada Saat Sosialisasi

\begin{tabular}{|l|l|l|l|}
\hline No & $\begin{array}{c}\text { Hal yang dirasakan } \\
\text { "PALING } \\
\text { MENARIK" }\end{array}$ & JUMLAH & $\%$ \\
\hline 1 & Menjaga kebersihan & 7 & 87.5 \\
\hline 2 & $\begin{array}{l}\text { Menambah } \\
\text { wawasan tentang } \\
\text { Covid 19 }\end{array}$ & 6 & 75 \\
\hline
\end{tabular}

Sumber: data diolah

Dari hasil kuesioner post-test yang diisi oleh 8 responden dapat dijelaskan bahwa hal yang dirasakan menarik oleh responden adalah bahwa $87,5 \%$ responden merasakan pentingnya menjaga kebersihan dan $75 \%$ responden menyatakan bahwa penting utnuk menambah wawasan terkait Covid-19.

Tabel 3 Hal yang Paling Tidak Menarik Pada Saat Sosialisasi

\begin{tabular}{|l|l|l|c|}
\hline No & $\begin{array}{l}\text { Hal yang dirasakan } \\
\text { "PALING TIDAK } \\
\text { MENARIK" }\end{array}$ & JUMLAH & $\%$ \\
\hline 1 & $\begin{array}{l}\text { Menggunakan } \\
\text { masker }\end{array}$ & 8 & 100 \\
\hline 2 & $\begin{array}{l}\text { Tidak bisa keluar } \\
\text { rumah }\end{array}$ & 5 & 62.5 \\
\hline
\end{tabular}

Sumber: data diolah

Terkait dengan hal yang tidak menarik seperti tampak pada Tabel 3. adalah 100\% responden menyatakan bahwa menggunakan masker dan $62,5 \%$ adalah tidak bisa keluar rumah. Hal ini bisa diterima karena pada dasarnya manusia adalah makhluk sosial dimana kegiatan bertemu dengan orang lain sudah menjadi kebutuhan, sedang pada masa pandemi ini diharapkan tetap tinggal di rumah dan membatasi kegiatan bersosialisasi.

Selain itu tim pelaksana juga mengadakan peninjauan lapangan terkait dengan pelaksanaan pengelolaan taman budaya yang mematuhi protokol kesehatan

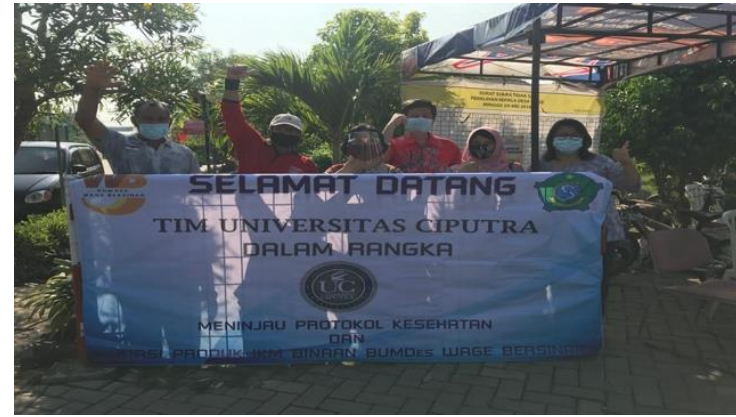

Gambar 23. Tim pelaksana abdimas melakukan peninjauan dari pelaksanaan pengelolaan taman budaya

\section{UCAPAN TERIMA KASIH}

Terima kasih kepada LPPM Universitas Ciputra yang telah memberi pendanaan kepada kegiatan pengabdian masyarakat dan juga kepada mitra BUMDes Wage Bersinar atas supportnya dalam kegiatan ini.

\section{KESIMPULAN}

Untuk dapat mengeloka taman budaya dengan memenuhi protokol Kesehatan maka perlu dilakukan 4 tahapan yaitu: (1) sosialisasi untuk memberikan pemahaman kepada masyarakat akan pentingnya $3 \mathrm{M}$ dan 3 WAJIB., (2) pelatihan dan demonstrasi mengenai bagaimana cara mencuci tangan yang benar menurut WHO, (3) stimulan empowering dengan memberikan spanduk, poster, masker dan tangki dan tempat cuci tangan yang diletakan pada lokasi strategis pada Taman Budaya di Lapangan Dewata, Desa Wage, dan (4) asset based community development dengan memperkuat kapasitas masyarakat dengan mengidentifikasi prioritas dan peluang untuk mendorong dan mempertahankan perubahan lingkungan yang positif berdasarkan tiga komponen penting yaitu fokus berbasis tempat, Keberhasilan gerakan mengelola Taman Budaya Dewata dengan protokol Kesehatan dan aman digunakan untuk menunjang kegiatan desa dan menjalankan ekonomi setempat, serta dapat menjadi contoh bagi lokasi lain yang memiliki sarana yang sama

\section{DAFTAR PUSTAKA}

BPS. (20017). Kecamatan Taman Dalam Angka 2017. https://sidoarjokab.bps.go.id/publication /2017/09/05/3ddbbab6a20d003d559a74 07/kecamatan-taman-dalam-angka- 
2017.html

Chaskin, R. R., Brown, P., Venkatesh, S., \& Vidal, A. (2017). Building community capacity. In Building Community Capacity. https://doi.org/10.4324/9781315081892

Craig, G. (2008). Preface: Defining Community and Its Development. Journal of Community Practice, 15(12), xxiii-xxvii. https://doi.org/10.1300/J125v15n01_a

Kementrian-Kesehatan, \& RepublikIndonesia. (2020). Begini Cara Mencuci Tangan Yang Benar. https://infeksiemerging.kemkes.go.id/inf o-corona-virus/begini-cara-mencucitangan-yang-bena

Marni, \& Margiyati. (2013). Pengantar Psikologi Kebidanan. Pustaka Pelajar. http://pustakapelajar.co.id/buku/pengant ar-psikologi-kebidanan/

Moscardo, G. (2008). Building community capacity for tourism development. In Building Community Capacity for Tourism Development. https://doi.org/10.1016/j.tourman.2009.0 8.009

Pusat Informasi dan Komunikasi COVID-19 KABUPATEN SIDOARJO. (2020). https://covid19.sidoarjokab.go.id/\#peta

Short, S. E., \& Mollborn, S. (2015). Social determinants and health behaviors: Conceptual frames and empirical advances. In Current Opinion in Psychology.

https://doi.org/10.1016/j.copsyc.2015.05 .002

Sidoarjokini. (2020). Didampingi Universitas Ciputra, BUMDesa Wage Bersinar Wujudkan Desa Wisata Budaya. https://sidoarjokini.com/2019/12/20/dida mpingi-universitas-ciputra-bumdesawage-bersinar-wujudkan-desa-wisatabudaya/

Squires, G. D. (2002). Review of Building Community Capacity. Contemporary Sociology, 31(2), 173-174.

Theodori, G. L. (2005). Community and community development in resourcebased areas: Operational definitions rooted in an interactional perspective. Society and Natural Resources, 18(7), 661-669.

https://doi.org/10.1080/0894192059095 